\begin{tabular}{|c|c|c|c|c|}
\hline Submission & Review Process & Revised & Accepted & Published \\
\hline $15-05-2020$ & $16-05 \mathrm{~s} / \mathrm{d} 24-08-2020$ & $28-12-2020$ & $30-12-2020$ & $31-12-2020$ \\
\hline
\end{tabular}

Jurnal Studi Sosial dan Politik, Vol. 4, No. 2, December 2020 (147-160)

ISSN 25978756

e ISSN 25978764

Jurnal Studi Sosial dan Politik Published by: FISIP Universitas Islam Negeri Raden Fatah Palembang

\title{
South Sumatra KPU Communication Strategy to Increase Voter Participation Rate in the 2019 Election
}

\author{
Muhamad Arif Setiawan \\ Pascasarjana Universitas Islam Negeri Raden Fatah Palembang \\ Email: muhammadsetiawan681@gmail.com \\ Fifi Hasmawati \\ Pascasarjana Universitas Islam Negeri Raden Fatah Palembang \\ Email: fifihasmir@gmail.com \\ KA Bukhori \\ Pascasarjana Universitas Islam Negeri Raden Fatah Palembang \\ Email: kabukhori76@gmail.com
}

\begin{abstract}
Elections are a democratic process which is carried out every 5 years and involves the public in exercising their voting rights. But in its implementation the voter participation rate has always been a big problem in elections, because in previous elections the community participation rate did not reach the target set. So this study entitled Communication Strategy of the South Sumatra KPU in Increasing Voter Participation Rates in the 2019 Election which uses a qualitative research approach to content analysis to obtain data based on interviews and analysts so as to produce a deep picture based on communication planning strategy theory by Hafied Cengara and theory Harold Lasswell to solve research problems regarding the communication strategy of the South Sumatra KPU in increasing voter turnout and knowing the evaluations conducted by the KPU for holding elections in South Sumatra. The communication strategy used is to use face-to-face methods directly and approach voter segmentation by maximizing the role of democratic volunteers. For the next election, the KPU must maximize the socialization carried out by conducting house-to-house campaigns to remind the public and provide an understanding of the community that exercising their right to vote is the most important part of the development process for the Indonesian people.
\end{abstract}

Keywords: Election, KPU and Community Participation.

\begin{abstract}
Abstrak
Pemilu adalah sebuah proses demokrasi yang di laksanakan setiap 5 tahun sekali dan melibatkan masyarakat dalam menggunakan hak suaranya. Namun dalam pelaksanaannya angka partisipasi pemilih selalu menjadi persoalan besar dalam pemilu, karena pada pemilu-pemilu sebelumnya angka partisipasi masyarakat tidak mencapai target yang telah di tetapkan. Maka tujuan penelitian ini untuk menganalisis strategi
\end{abstract}


Muhamad Arif Setiawan, Fifi Hasmawati \& KA Bukhori, South Sumatra KPU Communication Strategy to Increase Voter Participation Rate in the 2019 Election, JSSP, Vol. 4, No.2, December 2020

komunikasi KPU Sumatera Selatan dalam meningkatkan angka partisipasi pemilih pada pemilu 2019 yang menggunakan penelitian kualitatif dan menggunakan teknik analisis isi untuk mendapatkan data-data berdasarkan hasil wawancara serta analis sehingga menghasilkan gambaran yang mendalam dengan berlandaskan teori strategi perencanaan komunikasi oleh Hafied Cengara dan teori Harold Lasswell untuk memecahkan permasalahan penelitian mengenai strategi komunikasi KPU Sumsel dalam meningkatkan angka partisipasi pemilih serta mengetahui evaluasi yang di lakukan KPU Penyelenggaraan Pemilu di Sumsel. Hasil temuan penelitian ini bahwa strategi komunikasi yang di gunakan ialah dengan menggunakan metode tatap muka secara langsung dan mendatangi segmentasi pemilih dengan memaksimalkan peran relawan demokrasi. Untuk pemilu selanjutnya KPU harus memaksimalkan lagi sosialisasi yang di lakukan dengan melakukan kampanye dari rumah ke rumah untuk mengingatkan masyarakat dan memberikan pemahaman terhadap masyarakat bahwa menggunakan hak pilih merupakan bagian terpenting dalam proses pembangunan bagi bangsa Indonesia.

Kata Kunci: pemilu, KPU dan partisipasi masyarakat.

\section{INTRODUCTION}

The KPU (General Election Commission) is an independent institution that has the task of organizing the implementation of the General Election (General Election) in Indonesia. Law Number 22 of 2007 concerning Election Administrators regulates the RI KPU, Provincial KPU, and Regency / City KPU as permanent election administering bodies and BAWASLU (Election Supervisory Agency) as the Election supervisory agency. In carrying out its duties, the KPU is responsible in accordance with the laws and regulations as well as in the implementation of all stages of the general election (General Election Commission, 2020).

From the aforementioned statutory regulations, KPUs were formed in every region in Indonesia, both at the provincial and district / city levels. SUMSEL (South Sumatra) is one of the provinces located on the island of Sumatra which currently has 17 cities in it and all of them have been in the form of an election management institution that we know as the KPU

In 1999, General Elections in Indonesia were carried out regularly and smoothly in accordance with the principles of democracy that embraced the Indonesian State. However, at the stage of the election implementation, the GOLPUT (Golongan Putih) number in Indonesia tends to increase with each implementation. Since postreformation in the 1999 election, the voting participation rate reached 92.6 percent and the number of non-voters was 7.3 percent (Sendhikasari D, 2013).

Subsequently, the participation rate in the 2004 elections experienced a quite drastic decline, namely down to 84.1 percent and the number of abstentions increasing to 15.9 percent. In the 2009 election, the level of voter participation decreased, reaching only 70.9 percent and the number of non-voters increased to 22.1 percent (Sendhikasari D, 2013). Whereas in the 2014 election, the participation rate increased by 75.11 percent (Pratomo, 2020).

In South Sumatra, based on data collected, the voter turnout rate in the 2009 Presidential Election reached $75.02 \%$, while in 2014 the participation rate decreased to $72.1 \%$, while in the 2019 simultaneous election the voter turnout rate in South Sumatra increased to 84.02. \% (South Sumatra KPU, 2020). From the data generated, this figure 
Muhamad Arif Setiawan, Fifi Hasmawati \& KA Bukhori, Strategi Komunikasi KPU Sumatera Selatan Dalam Meningkatkan Angka Partisipasi Pemilih Pada Pemilu 2019, JSSP, Vol. 4, No.2, Desember 2020 exceeds the national participation target of 77.5 percent (Aziz, 2020) The following is the percentage of the results of the Presidential Election in South Sumatra in 2009, 2014 and 2019:

\begin{tabular}{|c|c|c|c|c|c|c|c|}
\hline \multirow{2}{*}{ No } & \multirow{2}{*}{ Kab/Kota } & \multicolumn{2}{|c|}{ Pemilu 2009} & \multicolumn{2}{|c|}{ Pemilu 2014} & \multicolumn{2}{|c|}{ Pemilu 2019} \\
\hline & & DPT & Partisipasi & DPT & Partisipasi & DPT & Partisipasi \\
\hline 1 & Palembang & 1.070 .594 & 749.064 & 1.144 .014 & 759.609 & 1.126 .087 & 925.545 \\
\hline 2 & OKI & 504.961 & 404.835 & 556.137 & 421.286 & 523.263 & 442.382 \\
\hline 3 & Ogan Ilir & 279.043 & 202.520 & 301.226 & 202.235 & 288.973 & 249.127 \\
\hline 4 & OKU Timur & 433.249 & 363.213 & 476.372 & 377.651 & 487.124 & 409.882 \\
\hline 5 & OKU & 233.375 & 169.992 & 251.897 & 171.656 & 258.062 & 219.424 \\
\hline 6 & OKU Selatan & 231.080 & 179.926 & 260.387 & 187.847 & 269.099 & 227.762 \\
\hline 7 & Muara Enim & 491.046 & 373.250 & 536.090 & 391.426 & 417.526 & 359.054 \\
\hline 8 & Prabumulih & 111.389 & 84.744 & 133.212 & 89.427 & 131.191 & 114.890 \\
\hline 9 & Pali & & & & & 131.576 & 113.597 \\
\hline 10 & Lahat & 266.413 & 202.076 & 293.043 & 206.334 & 297.014 & 259.265 \\
\hline 11 & Empat Lawang & 171.237 & 107.038 & 181.487 & 109.779 & 200.425 & 169.070 \\
\hline 12 & Pagaralam & 94.494 & 69.765 & 104.520 & 71.228 & 104.522 & 92.330 \\
\hline 13 & Musi Rawas & 377.404 & 298.550 & 427.693 & 317.485 & 289.544 & 248.065 \\
\hline 14 & Lubuk Linggau & 140.245 & 99.524 & 154.693 & 103.990 & 160.885 & 135.088 \\
\hline 15 & Muratara & & & & & 148.678 & 125.938 \\
\hline 16 & $\begin{array}{l}\text { Musi } \\
\text { Banyuasin }\end{array}$ & 391.618 & 280.479 & 457.803 & 298.452 & 449.854 & 370.073 \\
\hline 17 & Banyuasin & 515.939 & 402.038 & 586.451 & 409.713 & 593.746 & 477.093 \\
\hline & & 5.314 .075 & & 5.865 .025 & & 5.877 .575 & \\
\hline & Jumlah & & $\begin{array}{l}3.987 .014 \\
(\mathbf{7 5 , 0 2 \% )}\end{array}$ & & $\begin{array}{l}4.118 .118 \\
(\mathbf{7 2 , 0 1 \% )}\end{array}$ & & $\begin{array}{l}4.938 .585 \\
(\mathbf{8 4 , 0 2 \% )}\end{array}$ \\
\hline
\end{tabular}

The increase in the public participation rate in the 2019 Presidential election was also balanced with the results of the election for the People's Representative Council of the Republic of Indonesia (DPR RI) which also experienced an increase. Where the results of the 2019 legislative election show a high participation rate, reaching $83.95 \%$, with the following data:

\begin{tabular}{|c|c|c|c|c|c|c|c|c|c|c|c|}
\hline \multirow{3}{*}{ No } & \multirow{3}{*}{ DAPIL } & \multirow{3}{*}{$\begin{array}{l}\text { Kabupaten/ } \\
\text { Kota }\end{array}$} & \multirow{2}{*}{\multicolumn{3}{|c|}{ Data Pemilih (DPT) }} & \multirow{2}{*}{\multicolumn{3}{|c|}{$\frac{\text { Penggunaan Hak Pilih }}{(\mathrm{DPT}+\mathrm{DPTb}+\mathrm{DPK})}$}} & \multirow{2}{*}{\multicolumn{3}{|c|}{$\begin{array}{c}\text { Tingkat Parmas } \\
(\%)\end{array}$}} \\
\hline & & & & & & & & & & & \\
\hline & & & $\mathbf{L}$ & $\mathbf{P}$ & Jumlah & $\mathbf{L}$ & $\mathbf{P}$ & Jumlah & $\mathbf{L}$ & $\mathbf{P}$ & Total \\
\hline 1 & 1 & Musi Rawas & 147.171 & 142.373 & 289.544 & 125.194 & 122.767 & 247.961 & 85,07 & 86,23 & 85,65 \\
\hline 2 & 1 & Musi Banyuasin & 229.124 & 220.730 & 449.854 & 186.586 & 183.011 & 369.597 & 81,43 & 82,91 & 82,17 \\
\hline 3 & 1 & Banyuasin & 300.992 & 292.754 & 593.746 & 238.654 & 238.439 & 477.093 & 79,29 & 81,45 & 80,37 \\
\hline 4 & 1 & Palembang & 557.261 & 568.826 & 1.126 .087 & 448.689 & 476.793 & 925.482 & 80,52 & 83,82 & 82,17 \\
\hline 5 & 1 & Lubuk Linggau & 79.449 & 81.436 & 160.885 & 65.583 & 69.375 & 134.958 & 82,55 & 85,19 & 83,87 \\
\hline 6 & 1 & Muratara & 74.488 & 74.190 & 148.678 & 62.717 & 63.178 & 125.895 & 84,20 & 85,16 & 84,68 \\
\hline 7 & 2 & $\begin{array}{l}\text { Ogan Komering } \\
\text { Ulu }\end{array}$ & 131.010 & 127.052 & 258.062 & 110.538 & 108.707 & 219.245 & 84,37 & 85,56 & 84,97 \\
\hline 8 & 2 & $\begin{array}{l}\text { Ogan Komering } \\
\text { Ilir } \\
\end{array}$ & 268.604 & 254.665 & 523.269 & 222.516 & 218.897 & 441.413 & 82,84 & 85,95 & 84,40 \\
\hline 9 & 2 & Muara Enim & 209.915 & 207.611 & 417.526 & 178.510 & 179.966 & 358.476 & 85,04 & 86,68 & 85,86 \\
\hline 10 & 2 & Lahat & 150.592 & 146.422 & 297.014 & 130.178 & 128.924 & 259.102 & 86,44 & 88,05 & 87,25 \\
\hline 11 & 2 & OKUT & 247.890 & 239.234 & 487.124 & 206.950 & 202.760 & 409.710 & 83,48 & 84,75 & 84,12 \\
\hline 12 & 2 & OKUS & 139.139 & 129.960 & 269.099 & 118.562 & 109.200 & 227.762 & 85,21 & 84,03 & 84,62 \\
\hline 13 & 2 & Ogan Ilir & 144.924 & 144.049 & 288.973 & 122.232 & 125.929 & 248.161 & 84,34 & 87,42 & 85,88 \\
\hline 14 & 2 & Empat Lawang & 101.957 & 98.468 & 200.425 & 85.349 & 83.721 & 169.070 & 83,71 & 85,02 & 84,37 \\
\hline 15 & 2 & Pagaralam & 53.319 & 51.203 & 104.522 & 46.828 & 45.434 & 92.262 & 87,83 & 88,73 & 88,28 \\
\hline
\end{tabular}


Muhamad Arif Setiawan, Fifi Hasmawati \& KA Bukhori, South Sumatra KPU Communication Strategy to Increase Voter Participation Rate in the 2019 Election, JSSP, Vol. 4, No.2, December 2020

\begin{tabular}{rrlcrrrrrrrr}
\hline 16 & 2 & Prabumulih & 64.536 & 66.655 & 131.191 & 55.423 & 59.096 & 114.519 & 85,88 & 88,66 & 87,27 \\
\hline 17 & 2 & Pali & 65.308 & 66.268 & 131.576 & 55.509 & 58.088 & 113.597 & 85,00 & 87,66 & 86,33 \\
\hline & & TOTAL & 2.965 .679 & 2.911 .896 & 5.877 .575 & 2.460 .018 & 2.474 .285 & 4.934 .303 & $\mathbf{8 2 , 9 5}$ & $\mathbf{8 4 , 9 7}$ & $\mathbf{8 3 , 9 5}$ \\
\hline
\end{tabular}

Seeing the figures above where there is a decrease in the voter participation rate before the implementation of the 2019 simultaneous elections, in a democratic process a decrease in the level of voter participation or an increase in the number of Golputs will have negative implications for the development of democratic quality (Soebagio, 2008). This phenomenon of decreasing voter turnout will certainly be a warning to the implementation of democracy in Indonesia. Although there is no rule in the law that says low participation makes elections invalid, public participation is very important, because elections are the most important phase in the life of a democratic country like Indonesia (Sendhikasari D, 2013).

The role of the KPU as election organizer has responsibility for the issue of voter turnout. People who do not come to TPS (polling stations) and do not exercise their voting rights will certainly be the responsibility of the KPU as the election organizer. Even though the issue of the people's desire to use their voting rights or not, one of which is influenced by the figure of the figure to be elected, the KPU must prepare and have a strategy carefully to mobilize people to come to the polling station and exercise their voting rights.

The phenomenon of the 2019 election is different from the previous elections, where in 2019 the implementation of PILEG (Legislative Election) and PILPRES (Presidential Election) was held simultaneously. This means that from the simultaneous implementation, the public is required to vote 5 times at the same time, starting from voting for candidates for President and Deputy, DPR RI, DPD RI, Provincial DPRD and Regency / City DPRD. Therefore, the KPU is obliged to facilitate voters so that they can vote easily through geographic access that is easy to reach / not far from the community, safe and precise implementation in accordance with the set time and the public can easily understand the ballot papers to be punched and put down. to the ballot box that has been prepared correctly.

Election is an implementation of one of the characteristics of democracy, where the people are directly involved, involved in determining the direction and political policies of the country for the next five years. In its implementation, every Indonesian citizen according to Law No. 3 of 1999 in article 28 is a citizen of the Republic of Indonesia, hereinafter referred to as a citizen who at the time of voting for general elections is 17 (seventeen) years old or has / has been married. right to vote.

According to Haedar Nashir, democracy is a political system and ideology based on the doctrine of "power of the people", namely the power of the people, by the people and for the people. That the people are the holders of the highest sovereignty in the government system. Democracy either as a doctrine or ideology or as a political system is seen as a better alternative than other political systems that exist in almost every nation and state (Nashir, p. 37.1999). In another sense, democracy can also be interpreted as a form or pattern of governance that includes active all members of society in the decisions taken by those who have been given authority (Taupan, 1989).

Other opinions say democracy is a paradox, on the one hand it can imply the guarantee of freedom and opportunities to compete and conflict, but on the other hand it 
Muhamad Arif Setiawan, Fifi Hasmawati \& KA Bukhori, Strategi Komunikasi KPU Sumatera Selatan Dalam Meningkatkan Angka Partisipasi Pemilih Pada Pemilu 2019, JSSP, Vol. 4, No.2, Desember 2020 can also imply order, stability and consensus. The key to reconciling paradoxes in democracy lies in the way we treat democracy. Democracy should also be treated solely as a method or process and not an end, let alone sacred. Thus the order, stability and consensus that are aspired to and formed are positioned as a result of the formation of a process full of freedom, persuasion and consensual dialogue (Fatah, 1994).

From the various opinions above, we can see that a democratic system is a state system that leaves its power in the hands of the people both in running a government where the leader is directly elected by the people and the system for administering it. So it is fitting that Indonesia, which adheres to a democratic system in every holding of popular elections, has a major role in determining its leader. In determining their choice, the community should not be intervened by individuals or groups who want their votes in the election.

In choosing a leader, everyone must pay attention in detail and thoroughly, because as good citizens who obey the rules of our government, we are encouraged to always follow election contestations in Indonesia. Even in Islam as stated in Surah AnNisa verse 59, then the MUI (Indonesian Ulama Council) Fatwa of 2009 all call on the public to participate in exercising their right to vote in electing leaders.

An expert on Islamic politics who is a Professor at Syarif Hidayatullah State Islamic University Jakarta KH Masykuri Abdillah when interviewed by the NU (Nahdlatul Ulama) Online team at the PBNU Building (Nahdlatul Ulama Executive Board) said the need to elect a leader, here that the first thing is that NU citizens must participate in politics, do not become abstainers and do not use their voting rights. Even participating in politics in choosing this leader can become mandatory for kifayah, which can become compulsory because this determines the future of the Indonesian nation which determines not only mundane issues but also religious issues (NU Online, 2020).

This shows that choosing a leader in an election implementation process is a recommendation in terms of religion, rights and obedience to the government. So obeying and respecting government policies is not an ordinary thing but an order by the State and Religion for its people to always obey the government carefully.

The KPU as an election management body is the result of a government formation that can legally be accounted for. Because the formation of the KPU as the institution that organizes elections has been regulated in law. As a good citizen, Golput is not a solution for this nation, what happens if the number of Golput is higher, it will affect the level of public trust in the government and even elected leaders are questioned for their legitimacy at the community level. As good citizens, we should provide solutions and full support for election management institutions to participate in increasing voter turnout.

To solve the problem in this study, a theory is needed, because theory has an important role in supporting the success of a study. Without a theory in research, a problem that is studied cannot be resolved properly. For this reason, in this study several theories will be appointed as a reference and basis for research thinking.

First, the communication strategy theory according to Hafied Cengara, which states that communication strategy is a form of communication delivery plans related to policies to achieve a goal (Cangara, 2013). This theory briefly explains that to solve the 
Muhamad Arif Setiawan, Fifi Hasmawati \& KA Bukhori, South Sumatra KPU Communication Strategy to Increase Voter Participation Rate in the 2019 Election, JSSP, Vol. 4, No.2, December 2020

communication strategy problem, it must start from a well-prepared communication delivery plan.

According to the researcher's analysis, the communication strategy theory expressed by Hafied Cengara is very appropriate to be applied to solve the problems faced in this study. The author considers the communication strategy implemented by the South Sumatra KPU in order to increase voter turnout in the 2019 election must begin with careful planning. KPU policy making in conducting socialization must be planned in advance so that what is conveyed can be understood and accepted by the community as its target.

Furthermore, as a supporting theory in this study, the theory of communication strategies was taken by Harold D. Lasswell. Laswell stated that the best way to explain communication activities is by answering the question "Who Says What In Which Channel To Whom With What Effect?".

To strengthen the communication strategy that is applied, everything must be linked with the components which are the answers to the questions in the Laswell formula. Who? (Who is the communicator?), Says What? (What message does it convey?), In Which Channel? (What media does he use?), To Whom? (Who is the communicant?), With What Effect? (What effect does it expect?) (Effendy, 2008).

From the phenomenon that has been explained, it means that the South Sumatra KPU has a big challenge to overcome this problem and achieve the national target that was announced, the KPU is also demanded to be able to change the paradigm of society that Golput behavior is not a concrete solution. "In the 2019 elections the national target for the voter turnout is 77.5\%." (Jurnaliston, 2020). So, the South Sumatra KPU must have the right communication strategy to exceed the national targets that have been set. This is because in the implementation of an Election the participation rate is an important element as a measure of the success of the Election.

This research will include several studies related to the problems that exist in this study regarding "Election communication strategies" in general as follows: First research by Harold Y. Pattiasina, (2015) The results of this study show the political communication strategy of PDI Perjuangan in winning the election, namely by providing information to the public, educating the public on the meaning and significance of the facts, providing oneself to accommodate the aspirations of the community, and publication aimed at the government and other political institutions. The success of the communication strategy of parties and candidates in campaign activities to create a positive response from the voting community is largely determined by the message and structure of the political message it has designed. Candidates need to compile the substance of a political message that is truly in line with the reality of the problems that occur in society.

Furthermore, research by Tohap Hasugian (2019). The results showed that the General Election Commission of Dairi Regency succeeded in increasing the turnout rate for regional head voters in 2018 by $7.08 \%$. This is inseparable from the strategy used by the Dairi Regency KPU in increasing the level of participation at the voter list updating stage in collaboration with the Population and Civil Registry Office and the socialization stage with the flagship program "KPU goes to onan". 
Other research is by, Daud M. Liando (2016). The results of this study indicate that the level of community political participation is very dynamic, but what becomes the problem is related to motivation. Most people admit that their choice is driven by transaction factors and elements of emotional closeness.

Other research from Anna Valliana (2017). The results show that the role of political communication on political participation is very important where political communication plays a very important role in the success or failure of a democratic party in addition to seeking public participation, it is also related to the delivery of information or political socialization of participation, factors that influence participation. politics besides political communication is because during his leadership the couple had no flaws. The obstacle that becomes an obstacle is the number of Islamic organizations that do not agree with the couple.

Furthermore, research from Chothijah Fanaqi (2018). The results of the research are as follows that the communication strategy carried out by the General Election Commission (KPU) Kab. Garut in the framework of the 2014 Election socialization to the Disability Group was effective because it could take advantage of the potential in three main areas, namely: Situational Knowledge, Goal Setting and Communication Competence. However, there are a number of notes on the evaluation results of the Democracy Volunteer Program (Relation) for groups with disabilities, such as; The approach pattern of the KPU in Garut Regency in the future is expected to be more specific in accordance with the level of need for each group of disabilities, the need to involve the community of SLB teachers as assistance for groups with disabilities, the need for clear supporting instruments in the next election socialization program, as well as the need for adequate financial support for socialization. elections for groups with disabilities can run optimally.

Other research related to voter participation by Ike Atikah Ratnamulyani and Beddy Iriawan Maksudi (2018). The results showed that social media users were increasingly massive among students as first-time voters in Bogor regency to access information about the election, namely as Twitter users 35\%, Facebook 28\%, and Instagram $28 \%$. Meanwhile, among politicians / political parties, the use of social media accounts is still low $(82.7 \%)$. Then the political campaign content of politicians on social media is less attractive $(94.2 \%)$. The suggestions for politicians include: (1) Optimal use of social media in election campaigns (2). The content of political messages should be tailored to the characteristics of first-time voters, such as: simple, practical, attractive and easy for them to understand.

In general, the similarity between previous research and research in this paper is that in terms of measuring community participation, a massive communication strategy is needed to carry out socialization activities to the community, while the difference that occurs between previous research and current research is that in terms of participation rates measured by the number of increases, but in a democratic process the quality of voters is also of particular concern in supporting the success of the election.

The research written in this article is very important to do, because in order to support government programs, especially the succession of the implementation of elections, an increase in the participation rate is needed so that the candidates who are elected from election contestation have strong legitimacy in the eyes of the public. In 
Muhamad Arif Setiawan, Fifi Hasmawati \& KA Bukhori, South Sumatra KPU Communication Strategy to Increase Voter Participation Rate in the 2019 Election, JSSP, Vol. 4, No.2, December 2020

addition, knowing the KPU's communication strategy in increasing the voter turnout rate will be useful as a guideline for the implementation of the next election so that the number of non-voters continues to decline and makes the community a qualified voter.

\section{RESEARCH METHODS}

The type of research used in this research is field research. What is meant by field research according to Suharismi Arikunto (Suharsimi, p.58. 1995) in the book the basics of field research research is a research that is carried out systematically by raising existing data in the field.

By using field research, researchers will find it easier to get the data needed to find out the communication strategy of the South Sumatra KPU in increasing voter turnout in the 2019 election. Because if we talk about voter turnout, we have to take data from the field results. From the results of the field data that will be processed by the author to determine the communication strategy used by the KPU.

The research method used is a qualitative research method. Qualitative research is considered by the author as the right method to find out the communication strategies used by the South Sumatra KPU in increasing the voter turnout rate in the 2019 election. Qualitative research methods in solving the problems studied use a survey method that is directly researched on research subjects which are used as respondents through interviews, observation and documentation (Moloeng, p.10. 2005).

The research approach used in this research is a case study approach. This research focuses intensively on one particular object which studies it as a case. Case study data can be obtained from all parties concerned, in other words, this study was collected from various sources (Nawawi, p.10. 2003). By utilizing a case study research approach, researchers can collect the data needed from all parties, especially data from the object of research, namely the South Sumatra KPU. From the South Sumatra KPU researchers can obtain various data sources, in relation to voter turnout rates, of course the South Sumatra KPU has this data, and the data that has been obtained will be combined with other data obtained such as activities that have been carried out.

The subjects in this study were the head of the South Sumatra KPU, Dra. Kelly Mariana as the main informant, then the Commissioner of the South Sumatra KPU for Socialization Amrah Muslimin, SE., MM and the KPU Commissioner for planning, data and information Hendri Almawijaya, M.Pd which was provided by the South Sumatra KPU.

Data collection techniques. To find information in order to obtain the necessary data, researchers used observation, interview and documentation techniques. Then the data analysis technique in this study uses content qualitative (content analysis). This type of research is mostly used to examine documents which can be in the form of text, images, symbols and so on to understand the culture of a particular social context. In qualitative media content analysis, all types of data or documents analyzed are more likely to be referred to as "text" regardless of the form of images, signs, symbols, moving images, and so on. Or in other words, what is called a document in qualitative content analysis is a form of symbolic representation that can be recorded or stored for analysis. This qualitative media content analysis refers to an integrative and more 

conceptual method of analysis to find, identify, process, and analyze documents to understand their meaning, significance, and relevance (Burhan, p.203, 2001).

Another opinion says that qualitative content analysis is a more in-depth and detailed content analysis to understand media content products and be able to relate them to the social context or reality that occurs when messages are made. Because all messages (text, symbols, pictures and so on) are social and cultural products of society. Qualitative content analysis is systematic, analytical but not as rigid as in quantitative content analysis. Categorization is used only as a guide, allowing other concepts or categorization to emerge during the research process (Kriyanto, p.247. 2006).

Based on the above opinion, the writer concludes that research based on this content analysis method utilizes the results of interviews which are made in written form be analysed the content. After obtaining data from interviews, observations, data in the form of documents and photos of the next activity the writer analyzes and is turned into written form. In addition, to complement this research the authors also analyzed every socialization that was carried out by the South Sumatra KPU.

\section{RESEARCH RESULT}

\section{A. South Sumatra KPU Communication Strategy to Increase Voter Participation Rate in the 2019 Election}

The strategy undertaken by the South Sumatra KPU in increasing the voter turnout rate is through face-to-face meetings and dialogue with the community both with the general public, early voters, people with disabilities, marginalized and coming directly to locations in districts / cities that have a flood hazard record, Disaster-Prone, ConflictProne and Inland Areas (Dra. K. Mariana, Interview, 20 February 2020)

The South Sumatra KPU tries to approach the community directly, by visiting locations that have been designated as targets of socialization, the South Sumatra KPU wants its presence to really be felt by the community as government representatives who have the mandate as an election management institution.

Furthermore, to increase the number of voter participation in the 2019 simultaneous election, the South Sumatra KPU carried out a preparation or planning before conducting the socialization, based on the results of the interview that the researcher got from the head of the South Sumatra KPU, the writer could analyze that the preparation made by the KPU before conducting the socialization was to determine targets the socialization that will be carried out, these targets include mapping which areas have below average voting participation, providing advocacy for community groups in isolated areas prone to manipulation, mapping areas where the previous year's Election was problematic, especially those involving election organizers, areas that allegedly having high Money Politic transactions, marginalized groups, disabilities, first-time voters, women and community leaders. Regarding information related to the implementation of elections in this case, those who act to convey this information to the public are all parties, be it the Election Organizer, in this case the KPU, or other parties such as government stakeholders, elements of the Indonesian National Armed Forces, community leaders, and mass organizations (A. Muslimin, Interview, February 20, 2020).

The involvement of Indonesian stakeholders in the implementation of elections is very important, to convey the KPU socialization cannot run alone, it requires 
Muhamad Arif Setiawan, Fifi Hasmawati \& KA Bukhori, South Sumatra KPU Communication Strategy to Increase Voter Participation Rate in the 2019 Election, JSSP, Vol. 4, No.2, December 2020

assistance from various elements of the existing government. Because basically Election is an activity that involves various elements in it to achieve success in its implementation.

\section{B. Evaluation of South Sumatra KPU in increasing voter turnout}

As a professional and independent institution with integrity, after the 2019 Election was carried out, the South Sumatra KPU also conducted an evaluation to measure the performance and strategies that had been implemented starting from the Election stage, the voting process, the counting process to the voter turnout, all of that was evaluated as a provision for the implementation of the next election to make it better.

The evaluation carried out by the KPU in terms of voter participation rates includes evaluating factors that affect the level of public participation such as: the Election Organizer (KPU) itself, election administration is the first evaluation discussed in the evaluation, because the results of the election on the day voting will determine the outcome of the election itself, especially the participation rate. If during the election there is chaos, it will cause conflict in the community and injure the image of the KPU as the organizing institution (H. Almawijaya, Interview, 20 February 2020).

In addition to evaluating from the implementation side, the KPU also evaluates the candidates in the election, because election candidates have an equally important role in helping the successful implementation of elections starting from the preparation to the voting day. To anticipate this, the KPU has provided an understanding for election candidates to compete fairly without playing cheating in the background, besides that the KPU has also provided information to candidates if they commit fraud, they will be sanctioned according to the existing rules (A. Muslimin, Interview, 20 February 2020).

KPU also conducted an evaluation of the behavior and attitudes of the success teams participating in the election, the success team also had an important role in the smooth running of the election. The KPU does not want conflicts during voting due to provocations made by individuals or from the success team of candidates. In addition to evaluating the success team, other evaluations carried out by the South Sumatra KPU were related to the timing of the voting, with a predetermined time that the voting process ended at $13.00 \mathrm{WIB}$ and ballots that had to be punched by the community were 5 ballot booths, the KPU must go the extra mile to save time so that there are not many long queues at the polling stations that cause commotion and chaos. The timing of this implementation is a serious evaluation for the future, because if the next election is held simultaneously, the election organizers must prepare a special strategy to anticipate things that can injure the implementation of the election.

Every Election in Indonesia, the participation rate is one of the main topics that are always discussed. Although the participation rate is not part of the technical implementation, it has an important role in measuring the success of the KPU as an election management institution in carrying out election activities every 5 years, both from the regional and national levels. 2019 is a moment of holding elections in Indonesia which are held simultaneously. In dealing with the increasing voter turnout, the South Sumatra KPU uses a communication strategy as expressed by Hafied Cengara and Harolld D. Lasswell when conveying socialization to the public so that the voter 

turnout rate in South Sumatra increases.

The success that the South Sumatra KPU has achieved is inseparable from a measured and systematic communication planning. So that the implementation of the 2019 simultaneous elections runs smoothly and the participation rate increases. The communication strategy planning that was carried out by the South Sumatra KPU before carrying out the activities that had been carried out was starting from processing voter data, understanding PKPU rules, making budget plans, mapping the segmentation of voters and target areas and preparing materials socialization according to community needs. In addition, the South Sumatra KPU also conducted a survey of elements of the election organizers starting from the Regency / City KPU in South Sumatra so that the election management apparatus understood the rules of activities and applicable SOPs (standard operating procedures).

The role of the election organizer as a communicator (who) in this case is the commissioner of the KPU of South Sumatra Province and their employees and all related elements from the top to the bottom level, they have an important role in socializing the 2019 Election. All of them have carried out their duties and functions properly, as evidenced by the implementation of outreach activities to the whole community with various voter segmentations and the implementation of the 2019 Election. The results of the socialization activities that have been carried out have provided an understanding of the public about the 2019 simultaneous elections.

The message (say what) conveyed to the public by the South Sumatra KPU is very complete from the categories of people who have been registered as voters, election stages, vision and mission of candidates who will participate in the election, the rights of voters, invitations to fight election hoaxes, anti Golput, anti money politics and anti sara politics, an invitation to vote at the polling station on April 17, 2019, to the socialization of moving to vote. All the stages that have been conveyed are steps of the South Sumatra KPU in conveying messages to the public. Because before conveying the message about the Election too far, the public must first know the initial steps, starting from determining the date for the 2019 Election to the stages of opening the candidate candidates, determining candidates, distributing serial numbers, then the campaign stage, voting time to the plenary meeting stage of determining the winner. election results. This message is very important to convey, with the aim that the public will understand the election mechanism right up to the voting.

In conducting the socialization, the South Sumatra KPU has used all media (in which channels) ranging from print, electronic, social media, billboards and banners and conducted MOUs (Cooperation) with several media to convey the socialization. All existing media are utilized by the South Sumatra KPU as a vehicle for socialization that is carried out by the KPU so that the message conveyed is more effective is received by all levels of society. It is undeniable that the media do have an important role to play in helping out with socialization.

People (to whom) who were divided into groups or mass organizations at the time of the 2019 election were also involved by the South Sumatra KPU by recruiting to become democracy volunteers. All of this is done to achieve honest, fair, straightforward and clean elections as well as to create good elections with integrity. KPU as the institution that organizes the Election has accommodated all the aspirations 
Muhamad Arif Setiawan, Fifi Hasmawati \& KA Bukhori, South Sumatra KPU Communication Strategy to Increase Voter Participation Rate in the 2019 Election, JSSP, Vol. 4, No.2, December 2020

that have been given by the community to realize the wishes of the community by providing integrated services through PPID (Information and Documentation Management Officials).

The expected effect of the implementation of the socialization is to increase public awareness, make people smart and qualified voters, increase voter turnout and increase public confidence in the democratic process. From all these points of hope so far the results have begun to show in the community. This is proven by the enthusiasm of the community who want to participate in a series of activities carried out by the KPU. And so far the image of the KPU in the community has also started to be good, meaning that the public is ready to give full trust to the KPU as the election organizer. When the enthusiasm among the community starts to get high, this is a positive signal for an increase in voter turnout when elections are held. So it is evident that in the 2019 Election, the participation rate of voters in South Sumatra increased and exceeded the national target.

A new finding in this study is that the authors see the South Sumatra KPU as an independent election management institution with integrity trying to become part of the community in order to get the full trust of the public and the public can easily understand what the KPU is saying so that the voter turnout rate increases. Because in its implementation, the South Sumatra KPU also wants to make the public as smart voters when determining their choice.

\section{CONCLUSION}

Based on the results of the research described above, it can be concluded that the communication strategy of the South Sumatra KPU in increasing the voter turnout rate in the 2019 election was carried out in the following ways: a. The South Sumatra KPU through all the elements involved in a massive dialogue directly with the community with a predetermined segmentation. b. Updating the voter list in collaboration with related elements and carrying out socialization stages by maximizing the role of democratic volunteers. c. Delivering messages to the public in detail and providing an understanding that elections are part of the process of developing state moral and mental development. d. Using all the media that are often consumed by the public. e. Build public awareness that one voice that they have determines the fate of the Indonesian nation.

The evaluation of the South Sumatra KPU in increasing the voter turnout rate is as follows: a. The results of the 2019 election are a benchmark for the success of the participation rate and election administration, where in the 2019 elections in South Sumatra it was proven that the participation rate had increased, the 2019 election results showed a figure $(84.02 \%)$ while in 2014 the participation rate was only up to $(72.01 \%)$. b. Socialization that is considered effective will guide the implementation of outreach in the next election. c. Synchronizing voter data and will always update voter data. d. Making quality voters and creating democracy with integrity with indicators that society determines their choices based on conscience. 


\section{DAFTAR PUSTAKA}

Almawijaya, H. (2020, Februari 20). Wawancara [Komunikasi pribadi].

Apriani, R., \& Maharani, M. (2019). Strategi Pemenangan Pasangan Calon Herman Deru Dan Mawardi Yahya Pada Pilkada Sumatera Selatan Tahun 2018. Jurnal Studi Sosial Dan Politik, 3(1), 17-27. https://doi.org/https://doi.org/10.19109/jssp.v3i1.4065

Aziz, M. (2020, Februari 29). Partisipasi pemilu di Sumsel 81,4 persen. antaranews.

Burhan, B. (2001). Metodologi Penelitian Kualitatif Aktualisasi Metodologis ke Arah: Ragam Varian Kontemporer. Jakarta: Rajawali Pers.

Cangara, H. (2013). Perencanaan dan strategi komunikasi. Jakarta: PT. Raja Grafindo Persada.

Effendy, O. U. (2008). Dinamika komunikasi. Remaja Rosdakarya.

Fanaqi, C. (2018). STRATEGI KOMUNIKASI KPU KABUPATEN GARUT DALAM SOSIALISASI PEMILU 2014 KEPADA KELOMPOK DISABILITAS DI KABUPATEN GARUT. Jurnal Komunikasi Universitas Garut: Hasil Pemikiran dan Penelitian, 4(1), 24-41.

Fatah, R. E. S. (1994). Masalah dan prospek demokrasi di Indonesia. Ghalia Indonesia. HASUGIAN, T. (2019). STRATEGI KOMISI PEMILIHAN UMUM DALAM MENINGKATKAN PARTISIPASI PEMILIH (Studi Pada Pemilih Pemula, Perempuan dan Kelompok Marjinal pada Pemilihan Bupati dan Wakil Bupati 2018 di Kabupaten Dairi Provinsi Sumatera Utara).

Jurnaliston, R. (2020, Februari 25). Pemilu 2019, KPU Optimistis Target 77,5 Persen Partisipasi Pemilih Tercapai.

Kompas. https://nasional.kompas.com/read/2018/09/18/12453331/pemilu-2019-kpuoptimistis-target-775-persen-partisipasi-pemilih-tercapai.

Komisi Pemilihan Umum. (2020, Februari 29). wikipedia. https://id.wikipedia.org/wiki/Komisi_Pemilihan_Umum

KPU SUMSEL, P. (2020). Dokumentasi. https://sumsel.kpu.go.id/web/index.php/home/awalku.html

Kriyanto, R. (2006). Teknik praktik riset komunikasi. Jakarta: Kencana.

Liando, D. M. (2016). PEMILU DAN PARTISIPASI POLITIK MASYARAKAT. 3, 15.

Mariana, Dra. K. (2020, Februari 20). Wawancara bersama Ketua KPU SUMSEL Ibu [Komunikasi pribadi].

Mikail, Kiki. "PEMILU DAN PARTAI POLITIK DI INDONESIA: Menanti Kebangkitan Partai Politik Islam Di Tahun 2019". Tamaddun: Jurnal Kebudayaan dan Sastra Islam 15, no. 1 (April 7, 2016): 107-148. Accessed December $31, \quad 2020$. http://jurnal.radenfatah.ac.id/index.php/tamaddun/article/view/444.

Moloeng, L. J. (2005). Metodologi Penelitian Kualitatif Edisi Revisi ke-19. Bandung: Remaja Rosdakarya.

Muslimin, A. (2020, Februari 20). Wawancara [Komunikasi pribadi].

Nashir, H. (1999). Pragmatisme politik kaum elit. Pustaka Pelajar.

Nawawi, H. (2003). Metode penelitian bidang sosial. Gadjah Mada University Press.

Online, N. (2020, Februari 20). Kriteria-Kriteria Nahdliyin untuk Pilih Pemimpin. NuOnline. https://www.nu.or.id/post/read/94239/kriteria-kriteria-nahdliyinuntuk-pilih-pemimpin

Pattiasina, H. Y. (2015). Strategi Komunikasi Politik PDI Perjuangan Kabupaten Maluku Tengah pada Pemilu 2014. Jurnal Penelitian Komunikasi Dan Opini Publik, 19(1), 124232. 
Muhamad Arif Setiawan, Fifi Hasmawati \& KA Bukhori, South Sumatra KPU Communication Strategy to Increase Voter Participation Rate in the 2019 Election, JSSP, Vol. 4, No.2, December 2020

Pratomo, Y. (2020, Februari 29). Ini-tingkat-partisipasi-pemilih-dari-pemilu-1955-2014 [Politik]. merdeka.com. https://m.merdeka.com/politik/ini-tingkat-partisipasipemilih-dari-pemilu-1955-2014.html

Ratnamulyani, I. A., \& Maksudi, B. I. (2018). Peran Media Sosial dalam Peningkatan Partisipasi Pemilih Pemula Dikalangan Pelajar di Kabupaten Bogor. Sosiohumaniora, 20(2), 154-161.

Sendhikasari D, D. (2013). Partisipasi Pemilih menjelang pemilu 2014. Pusat Pengkajian, Pengolahan Data dan Informasi (P3DI) Sekretariat Jenderal DPR RI, V(18/II/P3DI/September), 17.

Soebagio, H. (2008). Implication of the White Group in Perspective of the Democracy Development in Indonesia. Makara Human Behavior Studies in Asia, 12(2), 82. https://doi.org/10.7454/mssh.v12i2.171

Suharsimi, A. (1995). Dasar-dasar research.

Taupan, M. (1989). Demokrasi Pancasila.

Valiana, A. (2017). ANALISIS STRATEGI KOMUNIKASI POLITIK TERHADAP PARTISIPASI POLITIK PPEMENANGAN RUDI DAN PURNOMO DALAM PILKADA 2015 KOTA SURAKARTA. Jurnal Global Citizen: Jurnal Ilmiah Kajian Pendidikan Kewarganegaraan, 2(2). 